\title{
Povijest tuberkuloze - od tuberkulina do antituberkulotika (II. dio)
}

Željko Cvetnic* i Željko Dugac

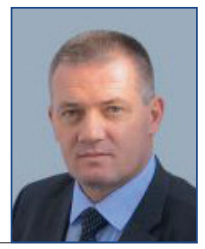

\section{Sažetak}

Otkriće uzročnika tuberkuloze $M$. tuberculosis 1882. godine bilo je jedno od najvažnijih otkrića u povijesti medicine, osobito u bakteriologiji. Obzirom da uzročnika tuberkuloze nije bilo moguće liječiti, postojali su mnogi pokušaji da se tuberkuloznim bolesnicima pomogne. Njemački liječnik Hermann Brehmer izgradio je prvi sanatorij 1857. godine u Görbersdorfu u Njemačkoj za liječenje i oporavak tuberkuloznih bolesnika. Jedan od osnivača lječilišta za tuberkulozu u Hrvatskoj (Brestovac na Sljemenu) bio je dr. Milivoj Dežman. Godine 1888. talijanski liječnik Carlo Forlanini napravio je prvi umjetni pneumotoraks uzrokujući kolaps pluća i napunio pleuralne šupljine dušikom. Kirurški tretmani tuberkuloze razvijali su se i primjenjivali sve do 1940-tih godina. Znatan iskorak u dijagnosticiranju tuberkuloze bilo je otkriće rentgentskih zraka 1895. godine. Robert Koch je otkrio 1890. godine tuberkulin, koji se nije zadržao kao lijek, ali je postao dijagnostičko sredstvo. Velikom napretku u borbi protiv tuberkuloze doprinijeli su Albert

Calmette i njegov suradnik Camille Guérin. Oni su uspjeli razviti BCG (Bacillus CalmetteGuérin) cjepivo protiv tuberkuloze koje je 1921. godine prvi put primijenjeno u bolnici u Parizu. Početkom 1943. godine Jörgen Eric Lehmann otkrio je paraminosalicilnu kiselinu (PAS), a 1944., biokemičar Selman Abraham Waksman i njegovi suradnici razvili su antibiotik streptomicin. Bili su to prvi lijekovi kojima se liječila tuberkuloza. Od sredine 1950-tih kombinaciji streptomicin i PAS dodan je i izoniazid, a kasnije su otkriveni i mnogi drugi lijekovi poput pirazinamida (1954.), a ethambutol i rifampicin uvedeni su u liječenje 1961. i 1963. pa je nastala nova era liječenja tuberkuloze, a mnogi su sanatoriji za tuberkulozu bili zatvoreni. Novi način liječenja tuberkuloze, zajedno s BCG-om, u zapadnom svijetu smanjio je umiranje od tuberkuloze za gotovo $90 \%$, a trajanje terapije skraćeno je s dvije godine na šest mjeseci. Povijest kontrole i liječenja tuberkuloze ušlo je u novo poglavlje.

Ključne riječi: sanatorij, tuberkulin, $B C G$, paraaminosalicilna kiselina (PAS), streptomicin

Dr. sc. Željko CVETNIĆ* ${ }^{*}$ dr. med. vet., akademik, (dopisni autor, e-mail: cvetnic@veinst.hr), Hrvatski veterinarski institut - podružnica Veterinarski zavod Križevci, Hrvatska; dr. sc. Željko DUGAC, dr. med., znanstveni savjetnik u trajnom zvanju, naslovni izvanredni profesor, Zavod za povijest i filozofiju znanosti, Hrvatska akademija znanosti i umjetnosti, Hrvatska 


\section{Uvod}

Otkriće uzročnika tuberkuloze 1882. godine bilo je jedno od najvažniji događaja u povijesti medicine, osobito u bakteriologiji. Obzirom da uzročnika tuberkuloze Mycobacterium (M.) tuberculosis prije nije bilo moguće liječiti nekim specifičnim lijekom. Postojali su mnogi pokušaji da se uzročnik određenim kemijskim supstancijama poput udisanjem antiseptika fenola uništi, što je izazivalo katastrofalne posljedice. Liječenje tuberkuloze se stoga usmjerilo na konzumiranje dobre i kalorične hrane, boravak na svježem zraku i suncu te odmaranje. Iako je i sam pojam "svježi zrak" u početku bio problematičan jer je određen broj tadašnjih liječnika smatrao da bolest prenosi isparavanjima prisutnim $\mathrm{u} z r a k u$, tzv. mijazmama (Cartwright i Biddis, 2006.). Polovicom XIX. stoljeća Hermann Brehmer u Göbersdorfu (Njemačka) izgradio je prvi sanatorij za liječenje ftize na višoj nadmorskoj visini uz svježi zrak i obilje hrane i šetnje po planinama (Frith, 2014.). Godine 1887. godine škotski liječnik iz Edinburga, Robert Philip, utemeljio je Dispanzer za sušicu kraljice Viktorije. Njegov princip je bio istraživanje čitave obitelji na tuberkulozu, a taj socijalni pristup temeljen je na istraživanjima Thomasa Beddoesa koji je još početkom XIX. stoljeća opazio da je plućna tuberkuloza obiteljska bolest. Philip je pokrenuo kampanju za prijavu oboljelih, izolaciju boravka u sanatoriju i pokretanju radnih kolonija u kojima bi se obavljali lakši poslovi. Godine 1889. slični dispanzeri su uvedeni i u New Yorku (Cartwright i Biddis, 2006.).

U potrazi za djelotvornim lijekom protiv tuberkuloze Robert Koch je 1890. godine održao prezentaciju na Desetoj međunarodnoj medicinskoj konferenciji u Berlinu, na kojoj je istaknuo da je izdvojio supstancu iz uzročnika tuberkuloze koja "može učiniti štetnim patogene bakterije koje se nalaze $u$ živom tijelu i učiniti to bez štetnog učinka na tijelo". Tvar je nazvao tuberkulin, a injekcije tuberkulina su ubrzo došle u terapiju kao lijek za liječenje tuberkuloze, ali jednako je brzo bio i ukinut zbog neučinkovitosti (Daniel, 2006.). Tuberkulin je prouzročio ozbiljne imunoreakcije i bio je daleko od „čarobnog lijeka“. Velika očekivanja donijela su razočaranja te je Kochov tuberkulin postao predmetom ozbiljnih kritika. U konačnici tuberkulin nije bio odbačen, a postao je i važno dijagnostičko sredstvo za dokazivanje tuberkuloze (Dormandy, 1999.). Daljnji korak u dijagnosticiranju i u konačnici borbi protiv tuberkuloze načinio je Wilhelm Konrad von Röntgen kroz svoje studije i otkrićem rentgenskih zraka iz 1895. Korištenje tih zraka je postalo glavna i učinkovita tehnika $u$ dijagnostici tuberkuloze (Martini i sur., 2018.). Valja istaknuti i to da su početkom XX. stoljeća u dijagnostici i liječenju tuberkuloze važnu ulogu imale i invazivne kirurške tehnike. Zahvaljujući Carlu Forlaniniju koji je 1912. godine poduzeo novu terapijsku intervenciju, stvorio je prvi umjetni intrapleuralni pneumotoraks izazvavši kolaps pluća (kolapsoterapija) zahvaćena tuberkulozom, ispunjavanjem pleuralne šupljine dušikom (Garbarino i sur., 2018.). Dva francuska bakteriologa Albert Calmette i Camille Guerin započeli su 1904. godine potragu za cjepivom protiv tuberkuloze na Institutu Pasteur u Lilleu, ali su tek 1921. godine prvi puta primijenili svoje cjepivo (Luca i Mihaescu, 2013.). Otkriće paraaminosalicilne kiseline (PAS) 1943. godine i streptomicina 1944. godine, prvog antibiotika i prvog baktericidnog sredstva protiv $M$. tuberculosis, drastično su promijenili povijest bolesti tuberkuloze (Daniel, 2006.).

Kao što se može zapaziti prošla su desetljeća od otkrića uzročnika (1882.) do otkrića antituberkulotika (1943. i 1944.). Tek se tada moglo naslutiti da će se tuberkuloza moći staviti pod kontrolu. 
Stoga $\mathrm{u}$ ovom radu želimo istaknuti najznačajnije pokušaje u dijagnostici, zaštiti i liječenju tuberkuloze.

\section{Sanatoriji}

Već je Hipokrat smatrao da svježi zrak, pravilna prehrana i tjelovježba pomažu oporavku od ftize. Krajem XIX. stoljeća uvedeno je jedno od prvih korisnih mjera za borbu protiv tuberkuloze, odnosno poboljšanje higijenskih uvjeta (Frith, 2014.). Osnivane su specijalizirane bolnice za skrb o tuberkuloznim bolesnicima, ali one su umjesto izlječenja bile mjesto za umiranje siromašnih ili za proučavanje bolesti. Općenito u prvoj polovici XIX. stoljeća smatralo se da tuberkulozu nije moguće izliječiti. Tadašnji medikamenti služili su samo za ublažavanje simptoma bolesti i bolova. Sve se to donekle promijenilo osnivanjem sanatorija (Waren, 2006.). Sredinom devetnaestog stoljeća talijanski liječnik Biagio Castaldi, koji je i sam obolio od plućne tuberkuloze, potvrdio je veliku učinkovitost zdravog načina života i planinsku klimu u sprečavanju širenja i oporavak od bolesti. Krajem devetnaestog stoljeća tuberkuloza je bila raširena, posebno među siromašnim svijetom, a sanatorijima su mogli boraviti gotovo svi staleži. Na tim su mjestima bolesnici mogli i raditi kako bi dobili odgovarajuće liječenje i hranu. Oni koji nisu boraviti u sanatorijima, dobivali su upute da o izolaciji u obitelji, ali i od drugih osoba s kojima su dolazili u kontakte (Daniel, 2006.).

Sanatoriji kao ustanove građeni su najprije u Njemačkoj. Tako je Njemački liječnik Hermann Brehmer izgradio je prvi sanatorij 1857. godine u Görbersdorfu, a jedan od njegovih pacijenata bio je i Peter Dettweiler koji je sličnu ustanovu izgradio u Falkenstainu 1876. godine. Edward Livingtone Trudeau, koji je i sam bolovao od tuberkuloze, projektirao je 1884. godine na jezeru Saranac u okružju planina Adinrondack u SAD niz kolibica i njegov je sanatorij bio prototip za mnoge slične u mnogim zemljama (Cartwright $\mathrm{i}$ Biddis, 2006.).

Hermann Brehmer je bio prijatelj velikog njemačkog prirodoslovca Alexandera von Humboldta koji mu je rekao da se tuberkuloza rijetko pojavljuje na visokim planinama Himalaja i drugim planinskim mjestima. Njegova je teorija bila da kisik na višoj nadmorskoj visini pospješuje srčani rad i time poboljšava zdravlje oboljelih od tuberkuloze. Brehmer je odlučio da svoju ideju provede u praksi i odlučio je da to bude u Görbersdorf, atraktivno mjesto na nadmorskoj visini od 600 metara, gdje je već 1854. godine počeo liječiti pacijente. Uz pomoć svojih utjecajnih prijatelja Alexandera von Humboldta i tadašnjeg poznatog znanstvenika Johanna Lucasa Schönleina izgradio je 1859. godine sanatorij (Waren, 2006.). Kako je rastao njegov ugled, rastao je i ugled sanatorija, do 1904. godine postala je sa svojih 300 ležaja najveća ustanova te vrste $\mathrm{u}$ svijetu. Bila je to impresivna građevina, s tornjevima nalik na tvrđavu. U sanatoriju je postojao poseban režim liječenja koji je uključivao hidroterapiju hladnom vodom, šetnju planinskim stazama i vježbe. Zanimljivo je da su za prehranu Brehmerovi pacijenti dobivali mlijeko, mađarsko vino za večeru, a francuski konjak prije spavanja, jer se vjerovalo da će to ojačati njihovo srce, poboljšati cirkulaciju i liječiti pluća. Tijekom prvog desetljeća u Görbersdorfu liječilo se 958 bolesnika, a smrtnost je bila svega $4,8 \%$ što je za to doba bila iznimno niski postotak (Waren, 2006., Frith, 2013., Cvetnić, 2019.). Brehmerove teorije nisu za vrijeme njegova života $u$ medicinskim krugovima bile prihvaćene, a ni pruska vlada nikada nije cijenila njegov doprinos, ali je zahvaljujći njemu postavljen smjer sanatorijskog liječenja koji je dominirao sljedećih sto godina (Waren, 2006.). 
Ranije spomenuti Peter Dettweiler bio je vojni kirurg, obolio je od tuberkuloze i oporavljao se u Görbersdorfu te je s poboljšanjem zdravlja postao Brehmerov pomoćnik. Godine 1875. osnovao je vlastiti sanatorij Falkenstein na brdima u blizini Frankfurta. Njegov način liječenja je bio malo drugačiji, on je za razliku od Brehmera koji je naglašavao vježbanje više zahtijevao odmor bolesnika. Njegove su se metode prihvaćale posebno u Engleskoj (Daniel, 2006., Waren, 2006.).

Treći poznati osnivač sanatorija bio je Edward Trudeau, koji je i sam kao mlad liječnik obolio od tuberkuloze, a inspiriran zapisima Brehmera, odlučio godine 1885. otvorio sanatorij Adirondack Cottage na jezeru Saranac u državi New York. Bio je prvi Amerikanac, koji je promicao izolaciju tuberkuloznih bolesnika kao način liječenja, smatrao je da razdoblje odmora i umjerene vježbe na planinskom, svježem zraku pridonosi izlječenju bolesti. Uz mnoge nepoznate ljude u sanatoriju su se liječili i mnogi poznati liječnici i najpoznatiji kanadski kirurzi oboljeli od tuberkuloze (Waren, 2006.). Trudeau je zahtijevao da njegovi pacijenti slijede prilično strog režim prehrane i vježbanja. Svakog su dana dobivali tri obroka, a čašu mlijeka svaka četiri sata. Pacijente su poticali da provode što više vremena na otvorenom. Postupno, pacijenti su provodili više vremena hodajući nego sjedeći, dok nisu mogli biti 8 do 10 sati dnevno na otvorenom, bez obzira na vremenske uvjete. Ono što je započelo kao jedna mala kućica, do 1900. godine postalo je malo selo, s 22 objekta, uključujući knjižnicu, kapelicu i ambulantu (Dormandy, 1999.).

Jedno od važnih mjesta sanatorijskog liječenje bio je i Davos u Švicarskoj. Još 1844. godine Luiz Ruedi primijetio je da skrofule u Davosu vrlo brzo zacjeljuju. Godine 1853. Aleksandar Spengler, spominje da kod lokalnog stanovništva u Davosu ne nalazi tuberkulozu. Dr. Fridrich Ungler, koji je bio upoznat s
Görbersdorfom, saznao je za Davos i sa Spenglerom napisao članak $\mathrm{u}$ kojem je za liječenje od tuberkuloze preporučio Davos. U Davosu i okolici izgrađeni su mnogi sanatoriji, a na liječenje su dolazili pacijenti iz cijele Europe i svijeta, posebno Brazila (Waren, 2006.).

\section{Sanatorij za tuberkulozu u Hrvatskoj}

U Liječničkom vjesniku broj 11 iz 1910. i broj 2 iz 1912. navodi se da je u Zagrebu na Sljemenu 1909. godine otvoreno lječilište za bolesti disala - Brestovac. Zavod je utemeljen subvencijama zagrebačke okružne blagajne i donacijama privatnih dobrotvora, a liječenje se provodilo po uzoru na Švicarske sanatorije za tuberkulozu. Zavod je imao vlastitu električnu centralu, vodovod i mljekarstvo. U Zavodu su se liječili pacijenti iz Hrvatske, Dalmacije i Bosne, liječilo se BrehmerDettweilerovom metodom, a rezultati liječenja bili su slični onima u Europi.

Jedan od osnivača i ravnatelj lječilišta za tuberkulozu Brestovac bio je Milivoj Dežman. Nakon studija medicine $u$ Grazu i Beču zaposlio se kao asistent na kirurškom odjelu, a kasnije je preuzeo službu liječnika Okružne blagajne. Njegovu posebnu pažnju pobudila je tuberkuloza s kojom se svaki dan susretao radeći s bolesnim radnicima. Tako je primjerice od svih uzroka smrti radnika u Zagrebu 1900. godine $53 \%$ njih bolovalo od tuberkuloze. Godine 1901. taj se udio popeo na $62 \%$, a 1902. na čak $72 \%$. Prateći razvoj i osnivanje lječilišta u Europi Dežman je razmišljao o osnivanju sanatorija u svojoj domovini kako bi se aktivno uključio u borbu protiv tuberkuloze (Ćepulić, 1940.). Lječilište Brestovac na Sljemenu $(834 \mathrm{~m}$ nad morem), bio je prvi korak u organiziranoj borbi protiv tuberkuloze. Bilo je to prvo specijalizirano lječilište za plućne bolesti u ovom dijelu Europe. U njemu je postojala knjižnica, kinodvorana, ali i gospodarski 
objekti poput mljekare, pekarnice i farme svinja (Dežman, 1934.).

\section{Uloga kirurških zahvata u liječenju tuberkuloze - pneumotoraks}

Manje je danas poznato kako su $u$ liječenju tuberkuloze određenu ulogu odigrali kirurški zahvati i različite druge invazivne tehnike. U početcima su za liječenje tuberkuloze korištena anatomska i fiziološka stanja koja su slučajno opažena prilikom drugih bolesti. Prvi takav slučaj opisao je 1696. godine Giorgio Baglivi, koji je primijetio da se klinička slika tuberkuloze bolesnika koji je pretrpio pneumotoraks kao rezultat rane zadobivene mačem poboljšala. Kasnije godine 1771 . Edmond Claude Bourru, ukazuje na poboljšanja stanja nakon kolapsa pluća. Godine 1885. Edouard Bernard de Cérenville, švicarski kirurg, a 1890. njemački kirurg Max Schede primijenili su novu metodu jednostrane resekcije rebara nazvanu torakoplastika, kako bi se smanjio volumen torakalne šupljine i dovelo do kolapsa tuberkuloznih šupljina. Godine 1888. talijanski liječnik Carlo Forlanini napravio je prvi umjetni pneumotoraks prouzrovšivši kolaps pluća, a pleuralne šupljine napunio dušikom (Garbarino i sur., 2018.). Kirurški tretmani tuberkuloze razvijali su se i primjenjivali sve do 1940-tih godina 20. st. Djelotvornost tih tretmana opisana je $\mathrm{u}$ različitim radovima tijekom desetljeća. Nakon što su otkrivena učinkovita antibiotska terapija (streptomicin i PAS), kirurški tretmani postupno su napušteni u korist sigurnijeg liječenja (Frith, 2014., Martini i sur., 2018.).

\section{Bojenje mikobakterija i rentgenske zrake}

Robert Koch je tijekom svoga rada uočio da alkoholno metilensko modrilo koje je još od 1875. razvio Karl Weigert, ne može obojiti tkiva da bi se vidio uzročnik tuberkuloze. Stoga je unaprijedio tehniku bojenja te je uz metilensko modrilo upotrijebio i koagulirani goveđi serum zagrijan na $40{ }^{\circ} \mathrm{C}$ te su se tada tkiva obojala smeđe, a same bakterije su pod mikroskopom bile svjetlo plave (Martini i sur., 2018.). Paul Ehrlich je znatno izmijenio i poboljšao protokol bojenja koristeći anilin, fuksin i gencian violet te se tek nakon toga pod mikroskopom moglo na plavoj pozadini vidjeti bacile tuberkuloze kao crvene mrlje (Sakula 1983.a, Boire i sur., 2013.). Franz Ziehl uveo je $u$ protokol bojenja umjesto anilina karbol fuksin, a Friedrich Neelson zamijenio je sumpornu kiselinu dušičnom pa su se bacili bojali jarko crveno. Tom su se metodom mogli dokazati tuberkulozni bacili, jer nakon što uzročnici tuberkuloze budu obojeni navedenim načinom više nisu mogli biti oprani ni kiselinom niti alkoholom. Potonja tzv. modificirana Ziehl-Neelsena tehnika koristi se i danas (Sakula, 1983.a).

Ključni iskorak u dijagnosticiranju tuberkuloze bilo je otkriće $X$ zraka za koje je Wilhelm Kondrad Von Röntgen dobio i Nobelovu nagradu 1895. godine. Ta se metoda koristi i danas u otkrivanju tuberkuloze u ljudi (Martini i sur., 2018.).

\section{Tuberkulin}

Nakon otkrića samog uzročnika Robert Koch je nastavio rad na tuberkulozi, osobito na pripremi lijeka protiv te bolesti. Godine 1890 . je iz kulture bacila tuberkuloze dobio koncentrirani tekući filtrat koji je nazvan tuberkulin ili "Kochova limfa" (Martini i sur., 2018.). U to je doba Koch bio uvjeren da se njime mogu liječiti životinje te je ujedno najavio testiranje na ljudima. Na glicerinskom bujonu M. tuberculosis uzgajao je šest tjedana, zagrijavao ga je na $100{ }^{\circ} \mathrm{C}$, filtrirao i isparavao toliko dok ga ne bi ostala desetina (Conti i sur., 
2004.). Dobiveni preparat - tuberkulin je bio bistra, smeđkasta tekućina koju je Koch sam sebi inokulirao u količini od $0,25 \mathrm{~cm}^{3}$. Inokuliranje tog koncentriranog tuberkulina je za posljedicu imalo napad groznice i porast temperature od $39,6^{\circ} \mathrm{C}$. Budući da je proizašao od Kocha, preparat je ubrzo došao u uporabu kao ljekoviti preparat za liječenje tuberkuloze (Daniel, 2006.). U ljudi je nakon aplikacije $(0,25 \mathrm{~mL})$, izazivao vrlo burne reakcije, poput upale na mjestu inokulacije, intenzivne tuberkulozne reakcije, visoke temperature, zimice i povraćanja te manje ili više opsežne nekroze na mjestu inokulacije. Tekućina bi prouzročila reakciju jedino ako se inokulirala supkutano, a osobito u osoba koje su imale tuberkulozu (Martini i sur., 2018.). Kochov je eksperiment pobudio interes svijeta i medicinskih časopisa. Engleski liječnik i tada već proslavljeni pisac Sir Artur Conan Doyle otputovao je u Berlin kako bi osobno svjedočio otkriću. Međutim, Koch nije htio podleći euforiji te je tvrdio da je još potrebno mnogo posla prije nego što tuberkulin može biti pušten u opću uporabu, budući da je prouzročio ozbiljne imunološke reakcije i bio je daleko od "čarobnog lijeka". Kako to obično biva velika očekivanja donijela su razočaranja te je Koch postao predmetom ozbiljnih kritika. Tuberkulin u konačnici nije postao lijek, ali je postao dijagnostičko sredstvo protiv tuberkuloze (Dormandy, 1999.).

Još dok je opisivao uzročnika tuberkuloze u ljudi, smatrao je da je uzročnik tuberkuloze goveda identičan, što je 1884. godine opisao u svome radu. Međutim, godine 1890. godine profesor Theobald Smith iz Harvarda objavio je svoje nalaze koji jasno dokazuju da su tuberkuloza goveda i ljudi različite. Koch je tvrdio da tuberkuloza u goveda nije toliko značajna i opasna za zdravlje ljudi i da su posebne preventivne mjere nepotrebne. Takav stav je imao veliku opoziciju i mišljenja su bila jako podijeljena. Godine 1903. osnovana je Kraljevska komisija za tuberkulozu, a njezino konačno izvješće 1911. godine odbacilo je Kochove stavove koji su podcijenili ozbiljnost goveđeg uzročnika tuberkuloze za javno zdravlje. Kraljevska je komisija preporučila mjere koje su kasnije stupile na snagu, a odnosile su se na politiku iskorijenjivanja tuberkuloze stoke i pasterizaciju mlijeka (Cvetnić, 2019.). Na preporuku slavnog danskog veterinara profesora Bernarda Banga danski parlament donio je Zakon o tuberkulozi, koji je predviđao obvezno tuberkuliniziranje stada goveda i klanje tuberkuloznih goveda pa je tuberkulin već 1892. uspješno upotrebljavan $u$ suzbijanju tuberkuloze goveda. Slične propise donijela je i Saska u Njemačkoj, Austrija i Mađarska (Dormandy, 1999.). Već je godine 1902. i u Hrvatskoj propisana tuberkulinizacija goveda kao dijagnostički postupak, a u Božjakovini su pozitivne reakcije dokazane u šest od deset krava buša (Frangeš, 1902.).

Godine 1907., bečki pedijatar i imunolog Clemens Freiherr von Pirquet koristio je kožne testove kako bi kod djece dijagnosticirao "latentnu tuberkulozu", izraz koji je sam uveo u medicinu. Reakcija na tuberkulin koji je nazvao alergija, otkrio je tuberkulozu čak i u pojedinaca koji nisu pokazivali znakove bolesti. Nekoliko godina kasnije (1910.) francuski liječnik Charles Montoux poboljšao je Pirquetovu metodu uz pomoć brizgalice za ubrizgavanje tuberkulina u slojeve kože, čime se mogla odrediti točna doza apliciranog tuberkulina. Američki biokemičari Florence Seibert i Esmond Long su 1930-tih dokazali aktivni protein $\mathrm{u}$ tuberkulinu iz kojeg se razvio pročišćeni proteinski derivat (PPD), što je u budućnosti omogućilo razvoj i sigurniju uporabu tuberkulinskog testa (Daniel, 2006., Martini i sur., 2018.). 


\section{Cjepivo protiv tuberkuloze - Bacillus Calmette-Guérin (BCG)}

U XIX. stoljeću postojali su pokušaji cijepljenja protiv tuberkuloze. U Italiji su to zagovarali Edoardo Maragliano, zatim Giovanni i Gaetano Petragnani Savioli, a u Francuskoj Albert Calmette i Camille Guérin. Već su 1891. godine Jacques-Joseph Grancher i Ledox Lebard vršili pokuse $s$ imunizacijom protiv tuberkuloze $s$ uzročnicima ptičje tuberkuloze. Kulture su bile podvrgnute različitim procesima smanjenja virulencije temeljene na Pasteurovim principima. Kada su se inokulirale zamorčićima nisu uspjele proizvesti imunost koja bi zaštitila sisavce. Godine 1895. Edoardo Maragliano tvrdio je da bi bilo poželjno proizvesti cjepivo $\mathrm{s}$ humanim tipom tuberkuloze. Vjerovao je da osušeni bacili mogu proizvesti posebne baktericidne tvari u organizmu koji je cijepljen. Von Behring i njegovi suradnici opisali su metodu nazvana ,jennerizacija“ goveda. Koristili su kulturu uzročnika humane tuberkuloze, koju su održavali više od šest godina u laboratoriju, a zatim ju osušili pod vakuumom, a u zamorčićima se njezina virulentnost pokazala slabom (Luca i Miahescu, 2013., Martini i sur., 2018.).

Velikom napretku u borbi protiv tuberkuloze doprinijeli su Albert Calmette i njegov suradnik Camille Guérin. Oni su uspjeli razviti cjepivo protiv tuberkuloze, BCG (Bacillus Calmette-Guérin). Ova se kratica rabi u većini svjetskih jezika, budući da su milijuni ljudi diljem svijeta ovim cjepivom zaštićeni od tuberkuloze (Daniel, 2006.). Calmette je tuberkulozu prepoznao kao glavni zdravstveni problem. Godine 1891. otvorio je prvu kliniku za tuberkulozu u Francuskoj i prvi francuski javni sanatorij za tuberkulozu (Montignyen-Ostrevant) 1905. godine. Kasnije 1919. godine preuzeo je mjesto ravnatelja Instituta Pasteur u Parizu, gdje je osnovao specijalni Laboratorij za tuberkulozu i BCG, a asistenti su mu bili Leopold Negre i Alfred Boduet (Daniel, 2006.).

Godine 1895. Calmette je imenovan direktorom novoosnovanog Pasteurovog instituta u Lilleu, a godine 1897., Camille Guérin imenovan je njegovim pomoćnikom. Zajedno su započeli rad koji će rezultirati BCG-om. Svi dotadašnji pokušaji proizvodnje cjepiva bili su bezuspješni. Kao što se često događa, slučajno su otkrili da određena suspenzija, u njihovom slučaju volovska žuč, smanjuje virulenciju $M$. bovis. Upravo je to slučajno otkriće navelo Calmettea i Guérina da pokrenu dugoročni projekt proizvodnje cjepiva iz atenuiranog bacila goveđe tuberkuloze te su 1908. taj proces proizvodnje i započeli. Kulturu M. bovis, izdvojenu iz vimena tuberkulozne krave dobili su 1902. godine od Edmonda Nocarda, francuskog veterinara i mikrobiologa $u$ Parizu. Kulturu su uzgajali na podlogama s dodatkom žuči, glicerina i krumpira. Izolat su supkultivirali svaka tri tjedna. Tek nakon pet godina (1913.) bili su spremni započeti s cijepljenjem stoke, no spriječio ih je početak Prvog svjetskog rata. Tijekom njemačke okupacije Lillea supkultivacija je unatoč znatno povećanoj cijeni krumpira i otežanoj nabavi prikladne žuči iz klaonice nastavljena. Do 1919., tijekom 11 godina napravljeno je oko 230 supkultivacija i takav izolat nije prouzročio tuberkulozu u zamorčića, kunića, goveda i konja (Sakula, 1983.b). Soj je prvo nazvan Billié Calmette-Guérin, ime je kasnije promijenjeno u Bacillus Calmette-Guérin (BCG), a prvi puta je primijenjen 1921. godine u bolnici Charité u Parizu. Cjepivo su prvi primijenila dva francuska liječnika Benjamin WeilleHalle i Rajmond Turpin i to peroralno na djetetu čija je majka ubrzo nakon porođaja umrla od tuberkuloze. Dijete je preživjelo i nije oboljelo od tuberkuloze. Cjepivo je postalo vrlo traženo i u sljedećih nekoliko 
godina cijepljeno je više od 100000 djece bez ozbiljnijih cjepnih komplikacija (Frith, 2014., Martini i sur., 2018.).

\section{Katastrofa u Lübecku}

Godine 1930. u njemačkom gradu Lübecku dogodila se katastrofa koja je znatno narušila povjerenje u BCG cjepivo. BCG cjepivo je dopremljeno iz $\mathrm{Pa}-$ steurovog instituta u Parizu, a pripremljeno je u Laboratoriju za tuberkulozu u Lübecku. Tada je cijepljeno 250 djece, a nakon četiri do šest tjedan veliki broj dojenčadi je dobilo tuberkulozu. Od 250 cijepljenih, 73 je umrlo u prvoj godini, a još 135 se zarazilo i oporavilo. Njemačka je vlada oformila komisiju i nakon 20 mjeseci istraživanja njihovo izvješće je oslobodilo sumnje na cjepivo BCG. Uzrok je bio nemar u Laboratoriju u Lübecku i onečišćenje cjepiva BCG virulentnim tuberkuloznim bacilima prilikom pripreme uzoraka. Povjerenje u cjepivo je bilo poljuljano, a Calmette i Guérin bili su predmetom velike kritike (Sakula, 1983.b). Kontroverze oko cjepiva nastavljene su još neko vrijeme. U skandinavskim zemljama, Švedskoj i Norveškoj, počeli su primjenjivati cjepivo BCG, a u Velikoj Britaniji vlasti su oklijevale u primjeni cjepiva, a izvori iz SAD-a su navodili da su izolirali virulentne bakterije tuberkuloze u uzorku BCG-a koji je isporučeno iz Pariza. Unatoč takvim uznemirujućim izvješćima, Calmette i Guérin bili su uvjereni da je BCG sigurno cjepivo. Rezultati su pokazali da cjepivo BCG nije davalo apsolutnu zaštitu, ali je znatno povećalo prirodnu otpornost. U djece koja su cijepljena BCG-om primarna se tuberkuloza razvila četiri do deset puta manje nego $u$ necijepljene. Isto tako, $u$ djece gotovo nikad nije zabilježen tuberkulozni meningitis ni milijarna tuberkuloza (Dormandy, 1999.). Rad na cjepivu nastavio se i nakon tragedije u Lübecku. U Švedskoj se nastavilo s praćenjem visokorizične skupine novorođenčadi i pokazalo se da se nakon sedam godina u samo jednog djeteta razvila tuberkuloza. Jednako je važna bila i primjena intradermalne metode, kojoj su mnogi bili znatno manje skloni zbog čestih lokalnih komplikacija poput ulceracija. Supkutana cjepiva pripremljena su prema metodi Löefflera i Matsda, gdje su bakterije ubijene toplinom, sušena, a zatim 15 dana zagrijavana na $70{ }^{\circ} \mathrm{C}$ (Martini i sur., 2018.).

Nakon Drugog svjetskog rata uslijedile su migracije i emigracije izgladnjelih ljudi što je rezultiralo velikim epidemijama tuberkuloze $u$ Europi i Aziji. Primjena BCG-a kao i proizvodnja liofiliziranog BCG-a olakšale su programe cijepljenja $u$ velikim razmjerima. Pod pokroviteljstvom UNICEF-a, BCG kampanja proširila se i na ostatak svijeta (Comstock, 1994.). Od 1945. do 1948. godine cijepljeno je više od osam milijuna djece u Austriji, Čehoslovačkoj, Finskoj, Grčkoj, Mađarskoj, Italiji, Poljskoj i tadašnjoj Jugoslaviji. Budući da nakon cijepljenja nije bilo kontrole stoga je nemoguće bilo provjeriti koliko je kampanja stvarno bila učinkovita. Kasnija iskustva su pokazala da je BCG zaštita široko varirala među populacijom u različitim zemljama, što je ovisilo o povijesnom statusu tuberkuloze, prehrani i imunosti stanovništva, načinu primjene i dozi cjepiva. Ipak smatra se da je kampanja i cijepljenje BCG-om spasilo nebrojeno mladih života (Dormandy, 1999.). Javno mijenje o cijepljenju BCGom je uglavnom bilo pozitivno, ali bilo je i protivnika, osobito u SAD-u, a u Velikoj Britaniji se dugo oklijevalo i razmatrala se primjena BCG-a. Godine 1950. pokrenuto je veliko istraživanje i napravljen je opsežni pokus učinkovitosti cijepljenja BCG-om na 50000 adolescenata i mladih. U sljedećih 20 godina pokazala su da cjepivo pruža $80 \%$ zaštitu od infekcije tuberkulozom. U siromašnim zemljama svijeta cijepljenje s BCG-om i dalje ima 
važnu ulogu, dok je u zapadnom dijelu svijeta uporaba smanjena i primjenjuje se u ugroženih skupina poput zdravstvenih djelatnika (Sakula,1983.b). Od početka primjene BCG-a pa do kraja XX. stoljeća računa se da je primijenjeno više od tri milijarde doza BCG-a (Roche i sur., 1995.).

Vidljivo je da se u prošlom stoljeću BCG cjepivo koristilo u raznim zemljama i odigralo svoju ulogu štiteći djecu i odrasle od tuberkuloze, međutim djelotvornost protiv plućne tuberkuloze je bila različita. Od početka XXI. stoljeća testirana su nova profilaktička cjepiva kako bi se što bolje kontrolirao plućni oblik tuberkuloze. Testirane su i različite formulacije novih cjepiva za tuberkulozu i vršena kliničkih istraživanja s ciljem postizanja trajne imunizacije (Martin, 2006.). Prema podatcima Svjetske zdravstvene organizacije (WHO) 2016. godine testirano je čak 13 cjepiva kandidata, koja uključuju cjepiva za prevenciju tuberkuloze, zatim cjepiva protiv latentne tuberkuloze, a temeljena su na snažnijem imunološkom odgovoru protiv $M$. tuberculosis i poticanju dugotrajnog imunološkog odgovora. Veliki izazov u razvoju cjepiva je nedostatak raznolikosti i eventualno otkriće novog kvalitetnog antigena koji bi se uključio u novo cjepivo protiv tuberkuloze. Postoje i nova hipoteza djelotvornosti cjepiva temeljena na tome da novi mikobakterijski antigeni mogu pojačati uništavanje bakterija (Orme, 2013., Fletcher i Scragel, 2016., Gengenbacher i sur., 2017., Kaufman i sur., 2017.).

\section{Otkriće lijekova protiv tuberkuloze}

U samim početcima Robert Koch je počeo koristiti zlatni cijanid te je primijetio da je imao učinak na rast $M$. tuberculosis, ali preparat svoj učinak nije pokazivao na inficiranim životinjama. Godine 1925. danski stručnjak Mollgaard uveo je terapiju sanokrizinom, ali pokazao se kao jako toksičan već u niskim dozama i većina zemalja ga je prestala koristiti (Benedek, 2004.). Tijekom XX. stoljeća počele su se otkrivati mnoge aktive molekula poput tisemikarbazona, paraaminosalicilne kiseline (PAS) ili hidrozid isonikotinske kiseline te se počela razvijati terapija protiv uzročnika tuberkuloze. Tijekom 1930-godina iskustveno je dokazano da se tuberkuloza ne može liječiti sulfonamidima, a 1940tih i penicilinom (Martini i sur., 2018.). Otkriće paraaminosalicilne kiseline (PAS) 1943. godine i streptomicina 1944. godine, prvog baktericidnog sredstva i prvog antibiotika protiv tuberkuloze drastično su promijenili povijest tuberkuloze (Daniel, 2006.).

Početkom 1943. godine Jörgen Eric Lehmann otkrio je paraminosalicilnu kiselinu. Toksikološke i farmakološke studije su zajedno na zamorčićima započele 1944. godine. Prof. Lehmann razvio je i metodu za mjerenje koncentracije PAS-a u krvi te je mogao uspoređivati farmakokinetična i farmakodinamična svojstva spoja. Već je u samim početcima opazio da spoj ima zanemarivu toksičnost. Početne kliničke studije urodile su velikim optimizmom. Već 1944. godine prvi je pacijent $u$ listopadu primio oralnu dozu lijeka, a 1947. godine provedeno je kliničko istraživanje na 176 pacijenata $u$ pet švedskih lječilišta. Rezultati istraživanja su bili revolucionarni, ali unatoč toga stručna je javnost bila prilično skeptična prema novom pripravku za liječenje tuberkuloze. Otprilike $\mathrm{u}$ isto vrijeme $\mathrm{u}$ New Jerseyu (SAD), biokemičar Selman Abraham Waksman i njegovi suradnici razvili su antibiotik streptomicin (Woodruff, 2014., Lehmann, 2015.).

Prošle su dvije godine od prvog pozitivnog dokaza i otkrića PAS-a in vitro profesora Lehmanna i objavljivanja članka o PAS u časopisu Lancet u siječnju 1946. Velika je količina podataka koji dokazuju učinkovitost PAS-a in vitro i in 
vivo, a na tržištu se pojavio 1948. godine. Usporede li se PAS i streptomicin, uočit će se da svaki ima svoje prednosti i nedostatke. Streptomicin je vrlo učinkovit, ali može prouzročiti gluhoću, a ima vrlo štetan učinak. Zapaženo je da uzročnik tuberkuloze vrlo često razvija otpornost te je u mnogih pacijenata nakon početnog poboljšanja došlo do recidiva. PAS je vrlo rijetko prouzročio ozbiljne štetne učinke, ali su vrlo često bili praćeni s manjim probavnim tegobama. Kasnije je shvaćeno da streptomicin uz PAS znatno smanjuje otpornost streptomicina i kombinacija ovih dvaju lijekova znatno je poboljšala liječenje tuberkuloznih pacijenata (Zumla, 2013., Lehmann, 2015.). PAS i streptomicin otkriveni su i razvijani gotovo $\mathrm{u}$ isto vrijeme 1943 . do 1945. godine. Na nacionalnoj razini, streptomicin je u SAD-u napravi veliki učinak, a što se tiče PAS-a tu je bilo puno skepse i kritika mnogih vodećih liječnika onog vremena u Švedskoj. Amerikanci su svoje kliničke podatke objavili ranije $\mathrm{u}$ članku $\mathrm{u}$ časopisu Lancet. Pretpostavljajući da će otkriće imati veliki odjek i većina neutralnih promatrača smatrala je da će Nobelovu nagradu podijeliti Lehmann i Waksman. Međutim, samo je 1952. godine Selman Waksman dobio Nobelovu nagradu za medicinu i fiziologiju za otkriće. To što Lehmann nije dobio Nobelovu nagradu za otkriće PAS-a je po mnogima jedna je od najvećih pogrešaka Skupštine koja odlučuje o dodjeli Nobelove nagrade. Ipak, nije to prvi puta da je Nobelova nagrada bila nedorečena, kao što se to kasnije tijekom vremena i na drugim primjerima pokazalo. Svakako otkrića oba lijeka - i PAS-a i streptomicina smatraju se jednim od najvažnijih otkrića u povijesti medicine (Lehmann, 2015., Cvetnić, 2019.).

Od sredine 1950-tih kombinaciji streptomicin i PAS dodan je i izoniazid (INH) koji je pronašao i razvio Gerhard Johannes Paul Domagk (McDermott,
1969.). Domagk je bio afirmirani znanstvenik koji je 1939. godine dobio Nobelovu nagradu za otkriće sulfonamida, a tek kasnije je razvio izoniazid (Anonymous, 2020.). Osim PAS-a (1943.), streptomicina (1944.) i izoniazida (1952.) otkriveni su mnogi drugi lijekovi poput pirazinamida (1954.), ethambutol i rifampicin uvedeni su u liječenje 1961. i 1963. Trajanje terapije variralo je od jedne do dvije godine, a uključivanjem rifampicina i pirazinamida u malim dozama pokazalo je djelotvornost već nakon šest mjeseci (Sotgiu i sur., 2015.). Sljedećih desetljeća razvijen je novi, kraći terapijski režim koji je obuhvaćao izoniazid, rifampicin, pirazinamid i etambutol $u$ kliničku praksu u 1960-ima bila je prekretnica koja je skratila trajanje liječenja do devet mjeseci, a kada se rabi režim koji sadržava pirazinamid, do šest mjeseci (Zumla i sur., 2013.).

Novi način liječenja tuberkuloze, zajedno s BCG-om, u zapadnom svijetu smanjuje smrtnost od tuberkuloze za gotovo 90 \%. Nastala je nova era liječenja tuberkuloze, a mnogi su sanatoriji za liječenje tuberkuloze zatvoreni. Znatno su poboljšane i donesene učinkovite mjere javnog zdravstva. Liječenje se proširilo i na bolesnike s latentnim tuberkuloznim infekcijama. Povijest kontrole i liječenja tuberkuloze ušlo je $\mathrm{u}$ novo poglavlje (Daniel, 2006.).

\section{Literatura}

1. Anon. (2020): Gerhard Domagk - Biographical. NobelPrize.org. Nobel Media AB 2020. Sat. 4 Jul 2020.https://www.nobelprize.org/prizes/medicine /1939/domagk/biographical/

2. BENEDEK, T. G. (2004): The history of gold therapy for tuberculosis. J. Hist. Med. Allied. Sci. 59, 50-89.

3. BOIRE, N. A., V. A. A. REIDEL, N. M. PARRISH and S. REIDEL (2013): Tuberculosis: from an untreatable disease in antiquity to an untreatable disease in modern times. J. Anc. Prev. Rem. 1:106.

4. CARTHWRIGHT, F. F. and M. BIDDISS (2006): Bolest i povijest. Naklada Ljevak d.o.o. Džin, gripa i tuberkuloza, str. 153-179. 
5. CONTI, A. A., D. LIPPI and G. F. GENSINI (2004): Tuberculosis: A Long Fight Against It and Its Current Resurgence. Monaldi Arch. Chest. Dis. 61, 71-74.

6. COMSTROCK, G. W. (1994): The International Tuberculosis Campaign: a pioneering venture in mass vaccination and research. Clin. Infect. Dis. 19, 528-540.

7. CVETNIĆ, Ž. (2019): Bolesti koje su mijenjale svijet. Medicinska naklada. Tuberkuloza- bijela kuga, str. 182-194.

8. ĆEPULIĆ, V. (1940): Naša nastojanja u borbi protiv tuberkuloze. Institut za suzbijanje tuberkuloze. Društvo za suzbijanje tuberkuloze, Zagreb.

9. DANIEL, T. M. (2006): The history of tuberculosis Resp. Med. 100, 1862-1870.

10. DORMANDY, T. (1999): The White Death.- A History of Tuberculosis. New York University Press. Pp. 139-146, 177-186, 332, 339-349.

11. DEŽMAN, M. (1934): Borba protiv tuberkuloze Uspomena s lječilišta Brestovac. Liječnički vjesnik $5,168-174$

12. FLETCHER, H. A. and L. SCHRAGER (2016): TB vaccine development and the end TB strategy: importance and current status. Trans. R. Soc. Trop. Med. Hyg. 110, 212-218.

13. FRANGEŠ, I. (1902): Die Busa. Inauguraldisertation, Universität, Leipzig.

14. FRITH, J. (2014): History of Tuberculosis. Part 2 the Sanatoria and the Discoveries of the Tubercle Bacillus. J. Milit. Veter. Health 22, 36-41.

15. GARBARINO, M. C., V. CANI and P. MAZZARELLO (2018): A century ago: Carlo Forlanini and the first successful treatment of tuberculosis. Lancet 392, 475.

16. GENGENBACHER, M., N. E. NIEUWENHUIZEN and S. KAUFMAN (2017): BCG - old workhorse, new skills. Curr. Opin. Immunol. 47, 8-16.

17. KAUFMANN, S. H, J. WEINER and C. F. VON REYN (2017): Novel approaches to tuberculosis vaccine development. Int. J. Infect. Dis. 56, 263-267.

18. LEHMANN, A. (2015): Jörgen Lehmann discovered drugs for both tuberculosis and blood clots. https:// akademiliv.se/en/2015/02/23830/. Pristupljeno 04.07. 2020 .
19. Liječnički vjesnik (1910): Lječilište Brestovac - Zavod za plućne bolesti zagrebačke okružne blagajne. 11, 387-388.

20. Liječnički vjesnik (1912): Lječilište Brestovac. 2, 82.

21. LUCA, S. and T. MIHAESCU (2013): History of BCG Vaccine. Maedica (Buchar), 8, 53-58.

22. MARTIN, C. (2006): Tuberculosis vaccines: past, present and future. Curr. Opin. Pulm. Med. 12, 186191.

23. MARTINI, M., G. BESOZZI and I. BARBERIS (2018): The never-ending story of the fight against tuberculosis: from Koch's bacillus to global control programs. J. Prev. Med. Hyg. 59, E241-E247.

24. MCDERMOT, W. (1969): The story of INH. J. Infect. Dis. 119, 678-683.

25. ORME, I. M. (2013): Vaccine development for tuberculosis: current progress. Drugs 73, 1015-1024.

26. ROCHE, P. W., J. A. TRICCAS and N. WINTER (1995): BCG vaccination against tuberculosis: past disappointment and future hopes. Trends Microbiol. 3, 397-401.

27. SAKULA, A. (1983a): Robert Koch: Centenary of the Discovery of the Tubercle Bacillus, 1882. Can. Vet. J. 24, 127-131.

28. SAKULA, A. (1983b): BCG. who were Calmette and Guérin? Thorax 38, 806-812.

29. SOTGIU, G., R. CENTIS, L. D॰AMBROSIO and G. B. MIGLIORI (2015): Tuberculosis treatment and drug regiments. Cold. Spring. Harb. Perspct. Med. 5 (5): a017822. doi. 10.1101/cshperspect.a017822.

30. WAREN, P. (2006): The evoluation of the sanatorium. The first half century 1854-1904. Can. Bul. Med. Hist. 23, 457-476.

31. WHO (2016): World Health Organization. Global Tuberculosis Report 2016. Available at: http:// www.who.int/tb/publications/global_report/en/. Accessed on $16^{\text {th }}$ August 2018.

32. WOODRUFF, H. B. (2014): Selman A. Waksman, winner of the 1952. Nobel prize for physiology of medicine. Appl. Environ. Microbiol. 80, 2-8.

33. ZUMLA, A., P. NAHID and S. COLE (2013): Advances in the development of new tuberculosis drugs and tretment regimens.. Nat. Rev. Drug. Discov. 12, 388-404. 


\section{History of tuberculosis - from tuberculin to antituberculotics (Part II)}

Željko CVETNIĆ, DVM, PhD, Academician, Croatian Veterinary Institute - Regional Department Križevci, Križevci; Željko DUGAC, MD, PhD, Scientific Advisor in Tenure, Associate Profesor, Department of History and Philosophy of Science, Croatian Academy of Sciences and Arts, Croatia

The discovery of the causative agent of tuberculosis Mycobacterium tuberculosis in 1882 was one of the most important events in medical history, especially bacteriology. Since the causes of tuberculosis were not treatable, there were various attempts to help tuberculosis patients. The German physician Hermann Brehmer built the first sanatorium in Görbersdorf, Germany in 1857 to treat tuberculosis patients. One of the founders of the tuberculosis sanatorium in Croatia (Brestovac on Mt. Sljeme) was Dr. Milivoj Dezman. In 1888, Italian doctor Carlo Forlanini performed the first artificial pneumothorax, causing lung collapse and filling the pleural cavities with nitrogen. Tuberculosis surgical treatments were developed and applied until the 1940s. A significant step forward in diagnosing tuberculosis was the discovery of the X-ray in 1895. Robert Koch discovered tuberculin in 1890, which initially was not a medicament but a diagnostic agent. Albert Calmette and his aide, Camille Guérin, achieved great progress in combatting tuberculosis. They succeeded in developing BCG (Bacillus Calmette-
Guérin), a vaccine against tuberculosis first administered at a Paris hospital in 1921. In early 1943, Jörgen Eric Lehmann discovered paraminosalicylic acid (PAS), and in 1944, biochemist Selman Abraham Waksman and his associates developed the antibiotic streptomycin, the first medicine to treat tuberculosis. In the mid-1950s, an isoniazid was added to the combination of streptomycin and PAS, while and many other medicines such as pyrazinamides were subsequently discovered (1954). Ethambutol and rifampicin were introduced to the treatment protocol in 1961 and 1963, respectively. A new era of treatment for tuberculosis has begun and many tuberculosis sanatoriums have since been closed. The new treatment of tuberculosis in the Western world, together with BCG vaccination, reduced tuberculosis deaths by nearly $90 \%$ and shortened the duration of therapy from two years to six months. With this, the history of tuberculosis control and treatment has entered a new chapter.

Key words: sanatorium; tuberculin; BCG; paraaminosalicylic acid (PAS); streptomycin 